This item was submitted to Loughborough's Research Repository by the author.

Items in Figshare are protected by copyright, with all rights reserved, unless otherwise indicated.

\title{
Book review: Qaddafi's Point Guard: the incredible story of a professional basketball player trapped in Libya's Civil War
}

\section{PLEASE CITE THE PUBLISHED VERSION}

http://dx.doi.org/10.1080/17430437.2015.1010822

\section{PUBLISHER}

(C) Taylor \& Francis (Routledge)

\section{VERSION}

AM (Accepted Manuscript)

\section{PUBLISHER STATEMENT}

This work is made available according to the conditions of the Creative Commons Attribution-NonCommercialNoDerivatives 4.0 International (CC BY-NC-ND 4.0) licence. Full details of this licence are available at: https://creativecommons.org/licenses/by-nc-nd/4.0/

\section{LICENCE}

CC BY-NC-ND 4.0

\section{REPOSITORY RECORD}

Swanson, Steve. 2019. "Book Review: Qaddafi's Point Guard: The Incredible Story of a Professional Basketball Player Trapped in Libya's Civil War”. figshare. https://hdl.handle.net/2134/20540. 
Qaddafi's Point Guard: the incredible story of a professional basketball player trapped in Libya's Civil War, by Alex Owumi with Daniel Paisner, New York, Rodale, 2013.

Qaddafi Point Guard, by Alex Owumi, is the real-life story of a professional athlete from the West caught up in the revolutionary movement now known as the Arab Spring. Due in large part to the remarkable circumstances, this story goes beyond what other depictions of playing sport in foreign lands have previously provided. Whilst other books have offered interesting perspectives on sport outside of Westernized environments, Qaddafi Point Guard provides a firstperson account of how pursuing a basketball career led to social circumstances notably more significant than those relating to sporting culture and fandom.

The story is autobiographical and written in the first-person by Owumi, a professional basketball player in his late 20s who, prior to his arrival in Libya, had played for a variety of basketball clubs throughout Europe. The early chapters of the book are written in an alternating narrative which shifts, often dramatically, between the crisis in Libya (written in the present tense) and the author's reflections on growing up in Africa and the USA, multiple collegiate experiences and his transition to professional basketball overseas. Some of the overriding themes throughout these chapters relate to how his life has been shaped by his commitment to basketball, his strong Christian faith and a collection of important relationships with family members, coaches and friends.

The book commences on a seemingly normal day as he prepares for an early morning workout with his coach in Benghazi. His mental perspective at the time seemed not too dissimilar from that of other professional athletes around the world; with thoughts relating to a big game on television, a commitment to skill improvement and an eye on upcoming contests. While somewhat aware of the waves of protests flaring up in neighbouring Tunisia and Egypt, the author admits that his focus had remained on basketball - his contributions, his team - leaving him fairly oblivious to the social tensions escalating rapidly around him. Although a confident grasp of the current political environment is initially portrayed here, this soon gives way to a sense of confusion and disbelief when confronted with the realities of the situation through conversation with his coach. A key aspect of this early writing revolves around the tension between a strong professional focus and the attention given to one's surroundings.

The first chapter tells the story of a young boy growing up in a large family in Lagos who takes an interest in a minority sport. A keen glimpse into a non-Western social culture is provided here, especially with regard to family structure and local customs. The author's perspectives on parental influence, regional role models and making do with sub-par facilities and coaching also allow for an interesting comparison to other sport environments around the world. Furthermore, a useful view is offered with regard to geographical social perspective, as growing up in Africa generally provided Owumi with a depiction of Muammar Qaddafi as someone who was respected and revered.

The chapters of the book are generally labelled by the primary geographic location of that period in the author's life. However, due to the multiplicity of locations covered in the book, this can be somewhat misleading at times as key occurrences in 
alternative locations are also described within. One such instance is at the end of the first chapter, where Owumi's family is transitioning to live in the USA by way of London. It was unfortunate that this section was not elaborated on more, as there were a variety of situations where conflicts in social norms were experienced by Owumi and in family members in relation to sport. Differences in dress code, facilities, physicality and participating in a more organized structure were a few areas where geographical nuances where identified in relation the early 1990s.

The second chapter provides additional perspective on how sports shaped Owumi's life while being raised in Boston from approximately 10 years of age. A main theme here is the interconnection between sport and education in the American system, and how noticeably more palpable certain sports of interest were in this environment. As an example, residing in a city where sports had such substantial presence, well-established teams (e.g. the Boston Celtics) and various sports personalities seemed to play a significant role in the interest and motivation to excel in sport. In addition, a poignant moment in this chapter deals with the clash between parental (and perhaps cultural) values and those more generally accepted within the U.S. high school sports environment.

The third chapter (and beginning of the fourth) is an account of the author's posthigh school educational journey which included attending four different colleges and universities. An overall theme in this chapter is the process of choosing the appropriate university to attend, and the tensions which accompany this decision in relation to academic versus sport priorities, and multi-sport participation verses specialization. This is a fascinating portion of the book, which is well suited for student-athletes approaching decisions about university attendance and those already participating in collegiate sports programmes. This chapter provides an explicit account of decision-making criteria in this situation, and concludes with an unconventional choice which proves instrumental in the author's career path.

The fourth and fifth chapters revolve around the transition to professional sports, and a variety of experiences encountered while playing professional basketball in France and Macedonia. Prior to these main reflections is an insightful account of the try-out and recruitment stages for professional basketball teams, as well as the tension surrounding the decision to sign with either domestic or foreign clubs. Along the way, more perspective is provided with regard to the struggle of maintaining relationships with family, friends and significant others whilst embarking on a professional career in foreign lands. One notable occurrence is also outlined where an out-of-character decision highlights the difficulty between adhering to both team goals and individual aspirations. In addition, the internal dialogue which emerges here on the relative importance of salary level over time also offers useful first-hand perspective. Finally, the fifth chapter concludes with a riveting account of challenges encountered with a mid-season team change between clubs from different foreign nations.

The sixth and seventh chapters represent the before and after of the critical incidents as witnessed on location in Benghazi. The sixth chapter delivers an enchanted view of how Owumi comes to realize he is playing for a basketball team owned by Colonel Muammar Qaddafi (and living in his son's apartment). A rare depiction of being introduced to the ruler of a country is also provided, with the question of acknowledging one's religious faith in the face of opposing views is also discussed. Whilst the benefits of this unique arrangement were soon recognized and appreciated, inherent disadvantages such as the negative 
consequences of losing games are also discussed. This section offers rare insight where elaboration would have been welcomed in relation to such an intriguing sport context.

It is between these two chapters where the chilling events of February 2011 become firmly entrenched in the main story of conflict. The events are visceral, provocative and should leave a lasting impression for readers of all walks of life. It is here that the reader realizes that this book is much less about basketball, and more so about survival. The author shares many difficult reflections relating to malnutrition, mental and emotional distress, and the confrontation of other atrocities which accompany armed conflict. Some of the most powerful moments of the book stem from the tension between self- preservation and doing the 'right thing' in situations of conflict.

The seventh chapter dealt with the realities of Owumi's situation, which included numerous communication challenges, the realization of no contact with friends, family and teammates, and most crucially the strategy for escape from his current location. Contact with local acquaintances is now questioned in relation to how an American will be viewed in the midst of the conflict. It is here that a different light is put on the power of sport to provide a connection between individuals with no common language and vastly different backgrounds.

The eighth chapter (and end of the seventh) is about the trials and tribulations experienced while trying to leave the Libyan boarders. This portion of the book is filled with even more thrilling and dangerous occurrences, while offering some of the deepest personal reflection in the face of dire circumstances. Conflict is evident here between Westernized contemporary expectations and the reality of a war-torn environment. As part of this remarkable chain of events, the chapter concludes with a collective act of compassion which transcends boundaries and provides affirmation of humanity.

The ninth chapter begins with another pleasant account of how sport can provide a connection between individuals from very different circumstances (religious, cultural and other). Another compelling aspect of this chapter related to the value of player- coach relationships in instances outside of the traditional sport environment. However, most notable in this chapter was the way in which sport was utilized as a vehicle for self- revival (mentally, physically and emotionally). This portion of the book initially leaves the reader slightly bewildered, but ultimately provides for a more well-rounded understanding of decisions made at this juncture of the story. A tension between the roles of sport versus family in the rehabilitation process provides for an interesting dilemma to be considered. Finally, the tenth chapter provides a very brief account of the book's culminating sport experience, and Owumi's return to the USA to reconnect with his family and friends.

Overall, this book is a captivating story of an individual's personal journey as a basketball player in different regions of the world. In comparison to numerous other books in the sport biographical landscape, Qaddafi's Point Guard is a refreshing read. Many relevant aspects of playing competitive sport over a lifetime are discussed in a down-to- earth non-pretentions manner, which in turn provides for a richer understanding of sport in society from a multinational perspective. Whilst several of these issues could be addressed from more of an academic perspective, the intention of this book appears to be to share a personal story of how sport can lead to extraordinary life experiences. 
Due to the wide range of topics covered, the text is recommended to various audiences. First, this book would be a valuable read for young people who aspire to play competitive sports at the university and/or professional levels. Second, this book would be an excellent choice for recommended reading in a variety undergraduate and graduate sport sociology courses. Finally, by providing a truly unique perspective on the intersection of sport and society, this book is also recommended to both sports and cultural enthusiasts in general. 